\title{
Pengembangan Material Serat Sabut Kelapa untuk Home Decor
}

\author{
Elna Wahyuning Tyas dan Ellya Zulaikha \\ Departemen Desain Produk, Fakultas Arsitektur Desain dan Perencanaan, \\ Institut Teknologi Sepuluh Nopember (ITS) \\ e-mail: ellya.zulaikha@gmail.com
}

\begin{abstract}
Abstrak-Indonesia adalah penghasil kelapa terbesar di dunia sebesar 18.3 juta ton pertahunnya. Sabut kelapa merupakan hasil samping dan merupakan bagian yang terbesar dari buah kelapa, yaitu sekitar 35 persen dari bobot buah kelapa. Dengan demikian maka terdapat sekitar 6,4 juta ton limbah sabut kelapa yang dihasilkan dan belum termanfaatkan. Sejauh ini, sabut kelapa merupakan bahan baku untuk industri otomotif, home appliance dan kerajinan seperti sapu dan keset khususnya di Indonesia. Penelitian dimulai dengan melakukan survey lapangan dan wawancara dengan distributor dan pengrajin serat sabut kelapa yang dilanjutkan dengan eksperimen material. Lalu penulis melakukan analisis terhadap eksperimen material tersebut, analisis luaran produk, dan studi bentuk melalui moodboard, studi user melalui persona, studi market melalui tinjauan produk sejenis dan studi pasar melalui segmentasi pasar dan positioning product. Melalui hasil eksperimen dan penelitian ini diperoleh bahwa produk serat sabut kelapa dapat dibentuk se-fleksibel mungkin dengan menganyam sabut kelapa pada rangka baja, sehingga bentuk yang diperoleh tidak hanya terbatas menjadi bentuk persegi empat seperti yang biasa diterapkan pada keset. Konsep produk yang dikembangkan pada penelitian ini adalah konsep rustic, karena menyesuaikan dengan karakter sabut kelapa yang cenderung kaku dan kasar. Sebagai langkah awal, produk yang dihasilkan adalah home décor untuk di café atau hotel.
\end{abstract}

Kata Kunci-desain produk, eco design, home decor, limbah serat sabut kelapa, rustic.

\section{PENDAHULUAN}

I NDONESIA adalah penghasil kelapa terbesar di dunia 18.3 juta ton pertahunnya. Sabut kelapa merupakan hasil samping dan merupakan bagian yang terbesar dari buah kelapa, yaitu sekitar 35 persen dari bobot buah kelapa. Dengan demikian maka terdapat sekitar 6,4 juta ton limbah sabut kelapa yang dihasilkan dan belum termanfaatkan. Serat alami merupakan serat yang berasal dari alam (bukan merupakan buatan atau rekayasa manusia). Serat alami ini dibagi menjadi 3 kategori, yaitu serat yang berasal dari tumbuhan, serat yang berasal dari hewan dan materi/anorganik.

Klasifikasi serat berdasarkan asalnya bahwa serat sabut kelapa sendiri merupakan jenis serat alami yang berasal dari tumbuhan kelapa yaitu buahnya. Sabut kelapa jika diurai akan menghasilkan serat sabut (cocofibre) dan serbuk sabut (cococoir) [1].

Berdasarkan proses pengolahannya, serat sabut kelapa sendiri memiliki 2 jenis serat yaitu serat pendek dan serat panjang. Serat pendek didapatkan dari hasil olahan menggunakan mesin penggiling sabut. Sedangkan serat panjang didapatkan dari hasil pengolahan manual, yaitu dengan bantuan tangan manusia dan proses yang panjang selama 3 bulan.

Sejauh ini, sabut kelapa merupakan bahan baku untuk industri otomotif, dan home-appliance. Di Indonesia sendiri serat sabut kelapa menjadi produk kerajinan tangan seperti sapu, keset dan juga dimanfaatkan sebagai media tanam, Berdasarkan penelitian sebelumnya, karakteristik sabut kelapa lebih kuat dan lebih tahan terhadap air. Namun, pengembangan produk dari serat sabut kelapa masih sangat minim. Sementara beberapa produk yang sudah ada kurang mengeksplorasi keunikan serat sabut kelapa. Salah satunya keset yang terbuat dari anyaman serat serabut kelapa. Oleh karena itu, serat serabut kelapa memiliki potensi untuk dieksplorasi lebih lanjut dan produk yang berpotensi diterapkan adalah home decor.

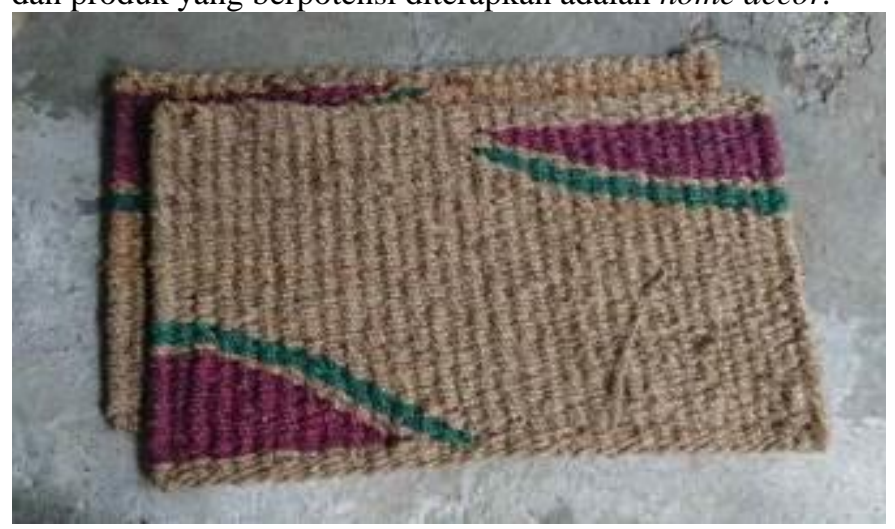

Gambar 1. Keset dari serat sabut kelapa.

\section{METODE PENELITIAN}

Pada penelitian ini, digunakan 5 metode penelitian yaitu studi tinjauan pustaka, studi perlakuan material, studi bentuk, studi pengguna, dan studi pasar.

Studi tinjauan pustaka termasuk studi tentang jenis serat alami, studi tentang spesies serat kelapa, studi tentang produk terdahulu yang terbuat dari serat sabut kelapa dan studi referensi desain. Hasil dari penelitian ini didasarkan pada analisis material yang diolah pada langkah berikutnya.

Dalam penelitian perlakuan serat kelapa, ada 3 langkah percobaan yang dilakukan. Pertama, eksperimen dengan metode cetak, metode pewarnaan, dan yang terakhir adalah percobaan menggunakan teknik anyam. Metode eksperimen dibagi menjadi 2 jenis, dengan menggunakan perekat dan polyester. Dalam metode pewarnaan, ada 2 jenis pewarna, pewarna sintetis dan pewarna alami. Dan dalam percobaan 
dengan teknik anyaman, menggunakan teknik anyam dengan bahan yang sama dan bahan campuran.

Kesimpulan dari studi perlakuan material adalah dasar untuk melanjutkan analisis proses produksi, analisis karakteristik produk dan analisis hasil produk.

Kemudian studi bentuk yaitu dengan membuat moodboard interior style, moodboard referensi bentuk dan semiotika berdasarkan analisis proses produksi, analisis karakteristik produk dan analisis output produk.

Setelah itu, dilakukan analisis persona, dan terakhir menentukan target pasar dengan melakukan analisis produk serupa, analisis segmentasi pasar, dan analisis posisi produk. Dari semua analisis akan menghasilkan konsep desain penelitian ini.

\section{HASIL DAN PEMBAHASAN}

Dari hasil eksperimen di dapatkan hasil untuk proses produksi sebeagai berikut:

\section{A. Pewarnaan}

Proses pewarnaan dimulai dengan memutihkan serat sabut kelapa terlebih dahulu menggunakan campuran waterglass dan $\mathrm{H} 2 \mathrm{O} 2$ sehingga pewarna alami dapat menyerap warna pada serat sabut kelapa, kemudian rebus 500gr pewarna alami menjadi 3liter air. Setelah itu rebus $150 \mathrm{gr}$ serat sabut kelapa dengan 2 liter larutan pewarna selama 1 jam. Untuk mendapatkan warna yang lebih gelap, kita perlu merendam serat kelapa berwarna dalam larutan tunjung (5gr tunjung untuk $500 \mathrm{ml}$ air) selama 3 menit. Dan untuk mendapatkan warna yang lebih terang, kita perlu merendamnya dalam larutan tawas (5gr tawas untuk $500 \mathrm{ml}$ air) selama 3 menit.

Pewarna alami yang digunakan adalah; tejer, jolawe, jambal, tingi, dan secang. Berikut merupakan hasil pewarnaan pada serat sabut kelapadapat dilihat pada Gambar 2. Berdasarkan hasil pewarnaan tersebut didapatkan beberapa palet warna, yaitu dapat dilihat pada Gambar 3.

\section{B. Pemilinan}

Serat sabut kelapa yang telah diwarnai lalu di pilin menjadi benang. Pemilinan dilakukan menggunakan mesin pilin serat sederhana. Mesin dapat digunakan untuk memilin serat 3 kali dalam satu waktu.

\section{Pembuatan rangka}

Pada saat yang sama, dapat membuat rangka baja sesuai dengan bentuk yang telah dirancang. Sebagai bingkai anyaman.

\section{Anyaman}

Anyaman dibuat langsung pada rangka baja yang telah dibentuk sesuai dengan desain.

\section{E. Proses Finishing}

Dalam proses finishing, anyaman yang sudah jadi lalu dibakar untuk menghilangkan sisa-sisa serat yang tidak rapih. Setelah dihilangkan sisa serat yang tidak rapih, anyaman lalu di coating menggunakan acrilyc waterbase.
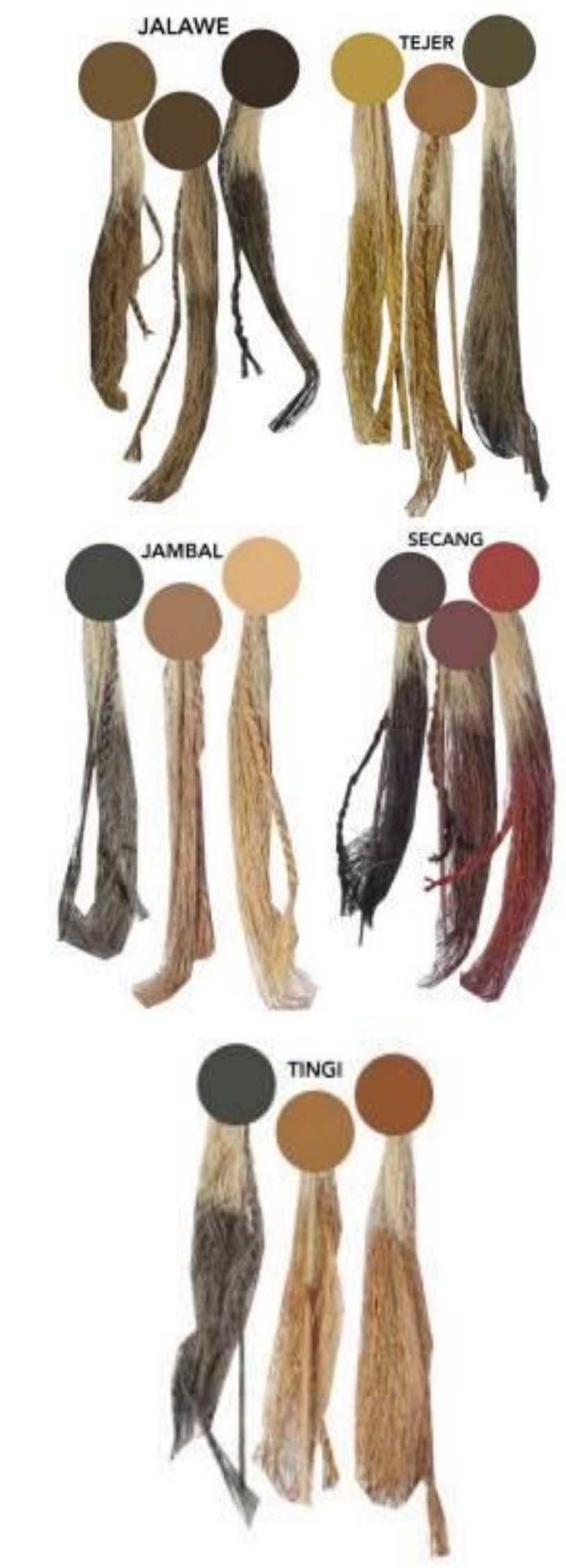

Gambar 2. Hasil pewarnaan pada serat sabut kelapa. 


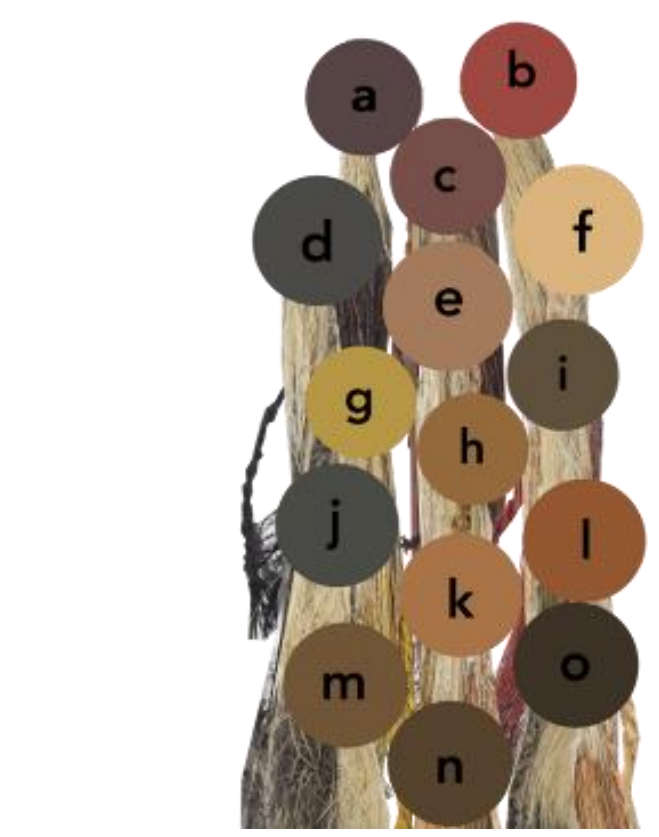

Keterangan Gambar:

a: Secang dicampur pengikat tunjung

b: Secang dicampur pengikat tawas

c: Secang dicampur pengikat kapur

d: Jambal dicampur pengikat tunjung

e: Jambal dicampur pengikat kapur

f: Jambal dicampur pengikat tawas

g: Tejer dicampur pengikat tawas

$\mathrm{h}$ : Tejer dicampur pengikat kapur

i: Tejer dicampur pengikat tunjung

j: Tingi dicampur pengikat tunjung

k: Tingi dicampur pengikat kapur

1: Tingi dicampur pengikat tawas

$\mathrm{m}$ : Jalawe dicampur pengikat tawas

$\mathrm{n}$ : Jalawe dicampur pengikat kapur

o: Jalawe dicampur pengikat tunjung

Gambar 3. Hasil palet warna.

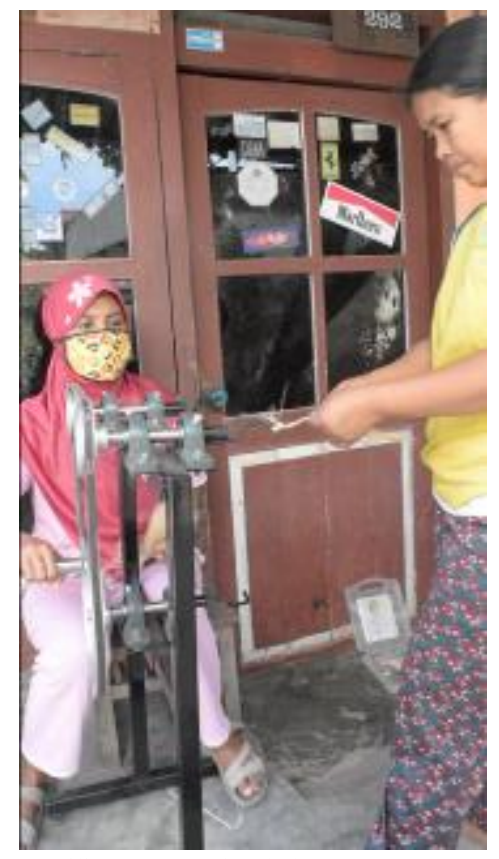

Gambar 4. Proses pemilinan serat sabut kelapa

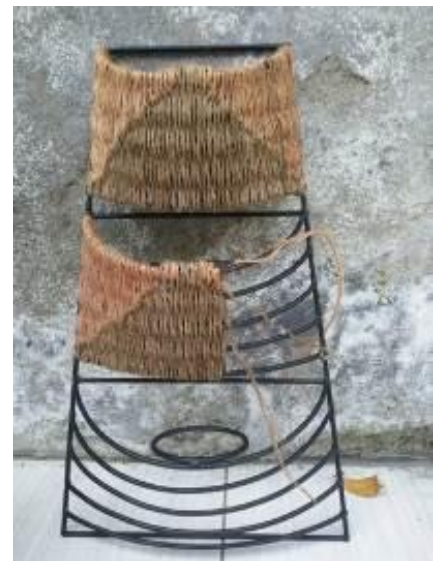

Gambar 5. Proses penganyaman.

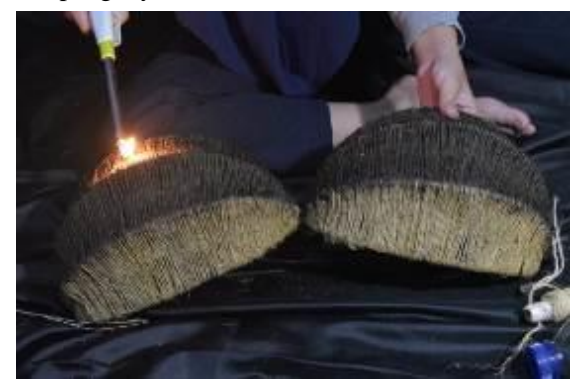

Gambar 6. Proses perapihan.

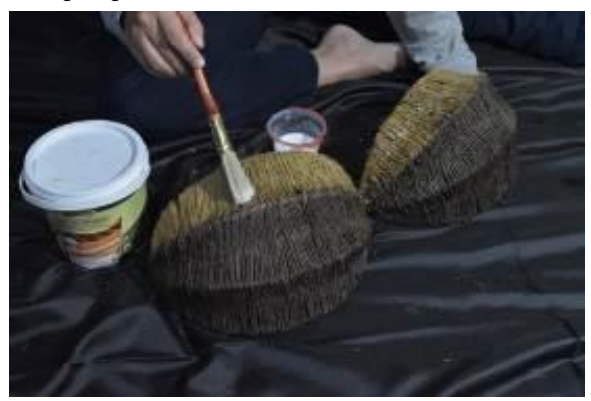

Gambar 7. Proses coating.

Berikut merupakan beberapa hasil dari produk serat sabut kelapa yang di buat menjadi vas bunga dan lampu:

1) Vas bunga satuan

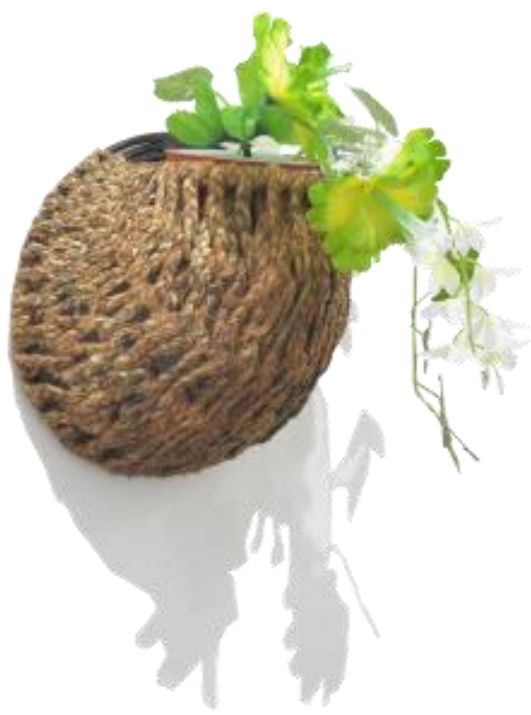

Gambar 8. Vas bunga single. 
2) Rak vas bunga

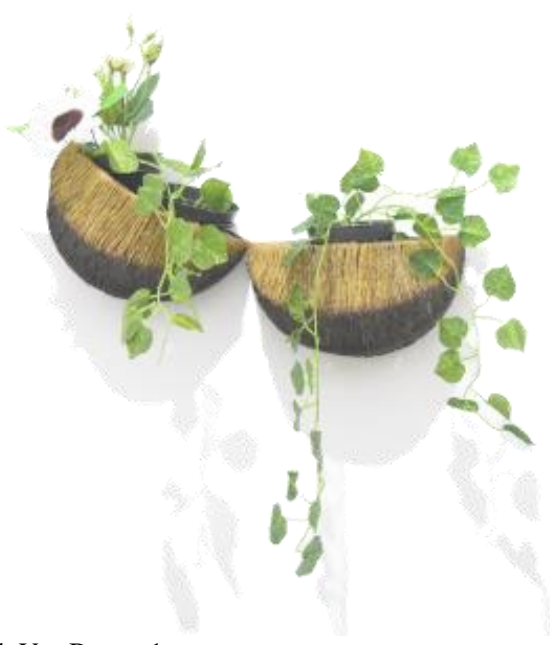

Gambar 9. Rak Vas Bunga 1.

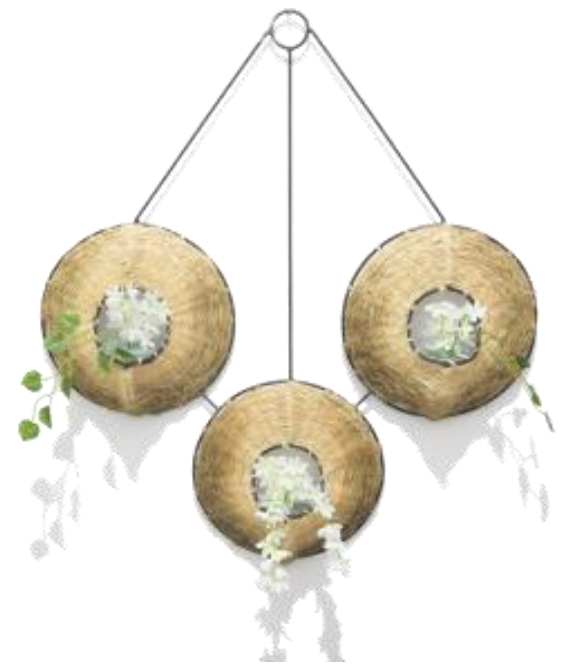

Gambar 10. Rak Vas Bunga 2.

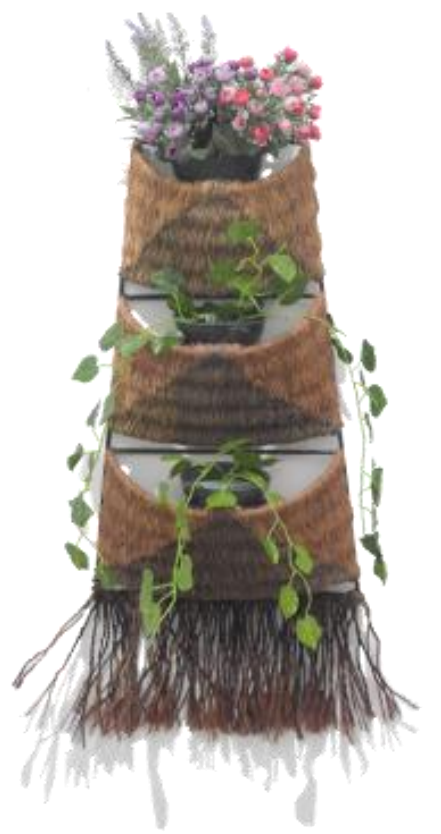

Gambar 11. Rak vas bunga 3.

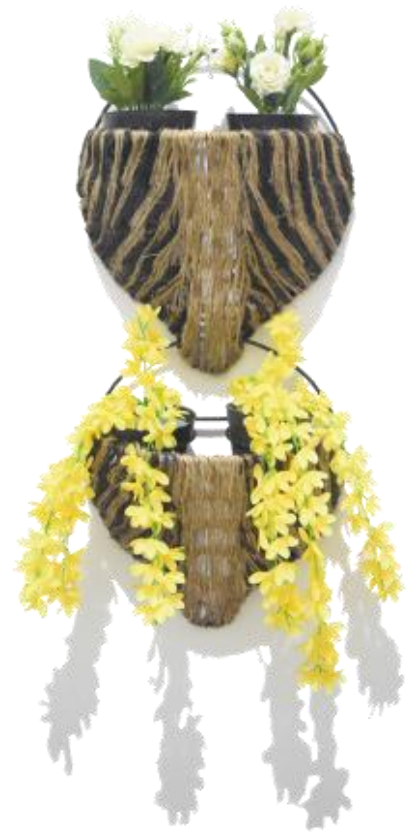

Gambar 12. Rak vas bunga 4.

3) Lampu Hias

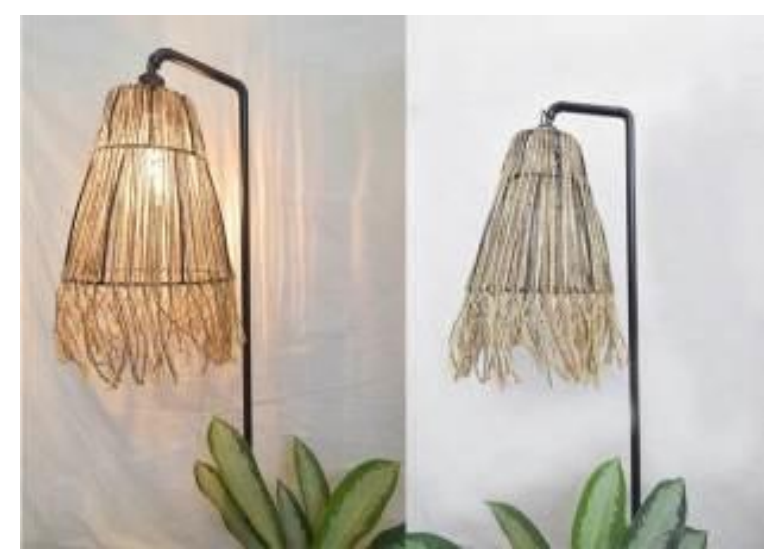

Gambar 13. Lampu 1.

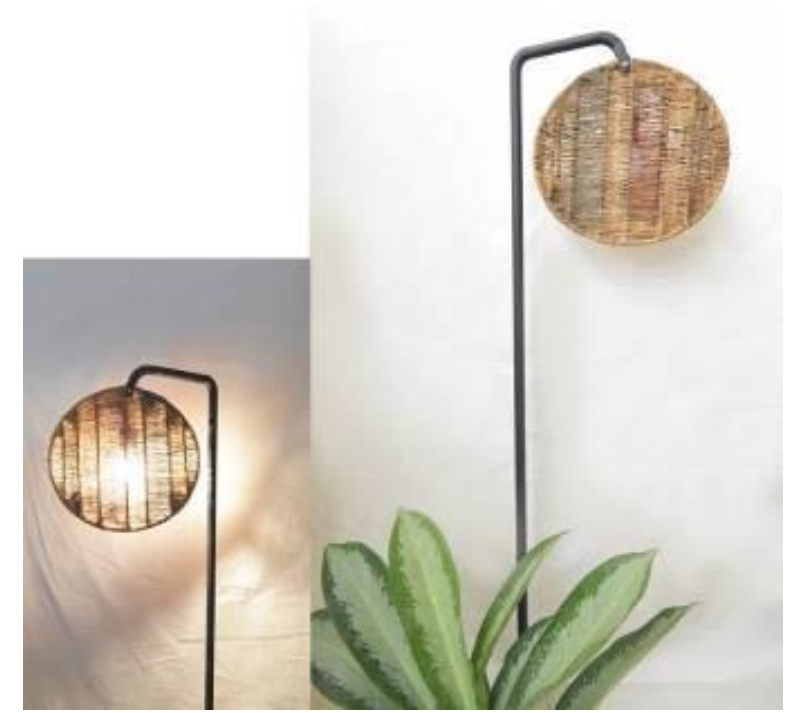

Gambar 14. Lampu 2. 


\section{4) Vas Modular}

Gambar 15. Vas modular 1.

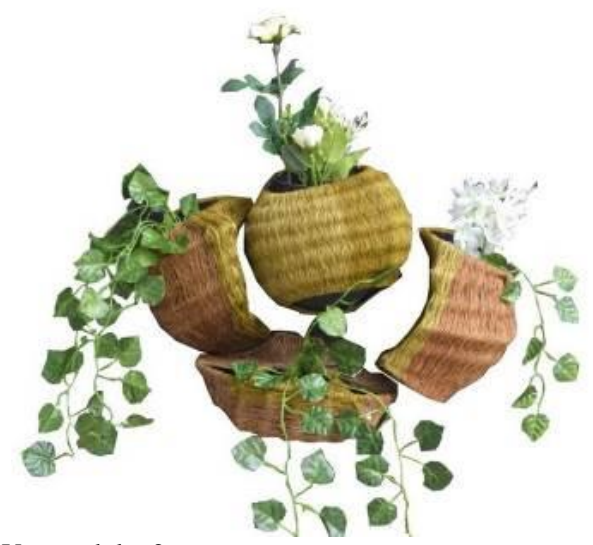

Gambar 16. Vas modular 2.

\section{KESIMPULAN}

\section{A. Kesimpulan}

Berdasarkan hasil penelitian dapat disimpulkan bahwa serat sabut kelapa dapat digunakan sebagai bahan yang ramah kingkungan dengan melakukan ekplorasi pada serat sabut kelapa itu sendiri melalui beberapa proses. Yang pertama bahwa proses pemutihan serat sabut kelapa menggunakan campuran antara waterglass dan $\mathrm{H} 2 \mathrm{O} 2$, hal ini dilakukan agar serat sabut kelapa lebih mudah diwarnai. Selanjutnya pewarnaan serat sabut kelapa dilakukan menggunakan pewarna alami seperti kayu tingi, kayu secang, kayu tegeran, kayu jambal, dan kulit kayu jalawe.

Lalu proses pemilinin serat menjadi benang dilakukan menggunakan mesin pemintal serat sederhana. Dan proses penganyaman dilakukan langsung pada pada rangka baja yang berukuran $5 \mathrm{~mm}$.Adapun produk yang dihasilkan dari peneltian ini adalah berupa vas bunga satuan (gambar 8), rak vas bunga (gambar 9-12), lampu (gambar 13-14), vas bunga modular (gambar 15-16).

Selanjutnya adalah pengembangan sistem anyaman pada serat sabut kelapa yaitu dengan menganyam serat sabut kelapa langsung pada rangka baja $5 \mathrm{~mm}$, sehingga bentuk yang didesain bisa fleksibel seperti pada gambar 15 dan gambar 16 dan dapat terealisasikan. Dari sini dapat dilihat bahwa produk eksisting keset dari anyaman serat sabut kelapa seperti pada gambar 1 dapat berkembang bentuknya menjadi bentuk yang flesksibel seperti pada gamabar 15 dan gambar 16.

\section{B. Saran}

Adapun beberapa saran yang dapat dilakukan untuk penelitian selanjutnya yaitu yang pertama kemungkinan pengembangan bentuk produk dari serat sabut kelapa masih bisa lebih luas lagi karena menggunakan rangka baja, bahkan bentuk yang ekstrim pun memiliki kemungkinan untuk dibuat. Lalu dapat melakukan analisis warna melalui eksplorasi motif. Dapat dikombinasikan dengan bahan logam lainnya seperti kuningan, tembaga, aluminium dan dapat dikombinasikan dengan bahan selain logam seperti rotan, kayu, bambu.

\section{DAFTAR PUSTAKA}

[1] B. Rindengan, "Karakteristik Daging Buah Kelapa Hibrida," 1995. 